\title{
Effect of season on haircoat characteristics and physiological parameters of Holstein-Gyr x Guzerá crossed heifers
}

\section{Efeito da estação do ano nas características do pelame e parâmetros fisiológicos em novilhas cruzadas Holandês-Gir x Guzerá}

\author{
Soraia Rage Rezende ${ }^{1 *}$; Mara Regina Bueno de Mattos Nascimento; \\ Susiandra Kloster Munhoz ${ }^{3}$; Natascha Almeida Marques da Silva²
}

\begin{abstract}
This study aimed to investigate haircoat characteristics and physiological parameters in summer and winter, morning and afternoon periods, of Holstein-Gyr x Guzerá crossed heifers in tropical environment. For this, twenty crossbred dairy heifers (Holstein-Gyr x Guzerá), reared in the city of Ibiá, Minas Gerais state, Brazil. Haircoat thickness, i.e. distance from skin surface until hairend, average hair length, number of hairs per unit area, hair angle to the skin surface, cardiac and respiratory rates, rectal and body surface temperatures were measured. Data underwent analysis of variance and the means were compared by $\mathrm{F}$ test at $5 \%$ significance, except heart and respiratory rates and skin temperature within the season, which were compared by Mann Whitney test at $5 \%$. For rectal temperature, the maximum value found was $39.53{ }^{\circ} \mathrm{C}$ in the summer afternoon. In the afternoon, rectal temperature was higher in summer compared to winter. Respiratory and heart rates and coat surface temperature were higher in the summer $(34.00$ movements min- $1 ; 78.60$ beats $\min -1 ; 37.97^{\circ} \mathrm{C}$ respectively) compared to the winter ( 27.47 movements minutes $-1 ; 58.72$ beats min- $1 ; 34,94^{\circ} \mathrm{C}$, respectively). Haircoat thickness and hair length were larger in winter $(0.73 ; 1.82 \mathrm{~cm}$, respectively) compared to summer $(0.49 ; 1.11 \mathrm{~cm}$, respectively). We concluded that the season of the year and day period interfere with most of the physiological parameters for thermoregulation and haircoat characteristics of crossbred heifers (Holstein-Gyr x Guzerá); however, they keep homeothermy, therefore are adapted to the region, and may be an alternative to be used by farmers of this region.
\end{abstract}

Key words: Bovine. Respiratory rate. Rectal temperature. Thermoregulation.

\section{Resumo}

Objetivou-se neste estudo investigar as características morfológicas do pelame e parâmetros fisiológicos no verão e no inverno, pela manhã e tarde, em novilhas cruzadas Holandês-Gir x Guzerá em ambiente tropical. Para isso, utilizaram-se 20 novilhas leiteiras mestiças oriundas do cruzamento de vacas cruzadas Holandês-Gir com touro da raça Guzerá, criadas no município de Ibiá, Minas Gerais. A espessura do pelame, ou seja, distância da epiderme até a superfície superior da capa dos pelos, comprimento médio dos pelos, número de pelos por unidade de área, ângulo de inclinação dos pelos em relação à superfície da epiderme, frequências cardíaca e respiratória, temperaturas retal e da superfície

\footnotetext{
${ }^{1}$ Médica Veterinária, Discente de Residência em Clínica e Cirurgia de Grandes Animais, Universidade de Franca, UNIFRAN, Franca, SP, Brasil. E-mail: soraiarezende03@gmail.com

2 Prof $^{\text {as }}$ Dr $^{\text {as }}$, Faculdade de Medicina Veterinária, Universidade Federal de Uberlândia, FAMEV/UFU, Uberlândia, MG, Brasil. E-mail: maran@ufu.br; natascha@ufu.br

${ }^{3}$ Discente do Curso de Graduação em Medicina Veterinária, Faculdade de Medicina Veterinária, FAMEV/UFU, Uberlândia, MG, Brasil. E-mail: susi.kloster@hotmail.com

* Author for correspondence
} 
corporal foram mensuradas. Realizou-se análise de variância e as médias foram comparadas pelo teste $\mathrm{F}$ a 5\%, exceto frequências cardíaca e respiratória e temperatura superficial dentro da estação, que foram comparadas pelo teste Mann Whitney a 5\%. Para temperatura retal o valor máximo encontrado foi de $39,53^{\circ} \mathrm{C}$ no verão, à tarde. À tarde a temperatura retal foi maior no verão em relação ao inverno. As frequências respiratória e cardíaca e temperatura de superfície do pelame foram maiores no verão $(34,00$

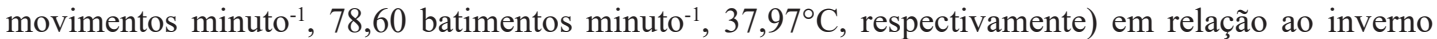

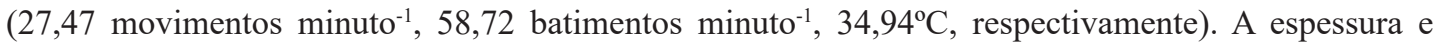
comprimento do pelame apresentaram-se maiores no inverno $(0,73 ; 1,82 \mathrm{~cm}$, respectivamente) em relação ao verão $(0,49 ; 1,11 \mathrm{~cm}$, respectivamente). A estação do ano e o turno interferem na maioria dos parâmetros fisiológicos de termorregulação e características de pelame de bezerras Holandês-Gir x Guzerá, entretanto, mantem a homeotermia e, portanto, são adaptadas a região, podendo ser uma alternativa a ser utilizada pelos criadores desta região.

Palavras-chave: Bovino. Frequência respiratória. Temperatura retal. Termorregulação.

\section{Introduction}

Several factors have affected dairy industry, mainly regarding thermal comfort. Under heat stress, animals reduce dry matter intake to decrease heat production, so they lose weight what interfere with production and reproduction (O'BRIEN et al., 2010). To check if an animal is or not under thermal comfort, physiological parameters of thermoregulation have to be measured, such as body temperature and respiratory rate. Thus, if bovines are being reared under thermal discomfort, a higher energy expenditure will be needed to maintain homeothermy, and consequently growth and performance will be compromised.

Since Brazil has an average annual temperature above $20{ }^{\circ} \mathrm{C}$, with maximum values above $30{ }^{\circ} \mathrm{C}$, reaching until $38{ }^{\circ} \mathrm{C}$, breeders must be concerned with physiological changes occurring in animals, as well as potential consequences to animal production and reproduction. In general, rectal temperatures in cattle reared in a warm environment are high, since they are being raised outside thermal comfort zone. Ideal temperature range for newborn cattle, heifers and lactating cows are respectively 18 to $21{ }^{\circ} \mathrm{C}$, 10 to $26{ }^{\circ} \mathrm{C}$ and 4 to $25{ }^{\circ} \mathrm{C}$ (FERREIRA, 2005). Moreover, in tropical and subtropical regions, cattle suffer pronounced effects of intense solar radiation (BOHMANOVA et al., 2007).

Bovines make use of several mechanisms to maintain thermal balance, as increasing heart and respiratory rates, increasing rectal and haircoat surface temperatures, searching for shaded places, increasing water intake and lowering dry matter intake, besides haircoat changes within a medium to long term (SILVA, 2000; BIANCHINI et al., 2006). Haircoat characteristics such as hair number, length and average diameter, as well as coat thickness, inclination angle also have a direct influence on thermal insulation, so that the animal could maintain homeothermy (FAÇANHA et al., 2010).

As the environmental temperature rises, latent heat dissipation (evaporation), either by increasing respiratory frequency or by activating sweat glands, sensible heat (related to the losses by convection, radiation, conduction) becomes higher. Under this condition, animals demand more energy for thermolysis, compromising its performance. An alternative being used by dairy cattle farmers in Brazil to mitigate negative effects of high temperatures is breeding. That is because different genetic compositions may interfere with physiological parameters of lactating cows (LIMA et al., 2013; CARVALHO et al., 2003).

Breeding is an important method of genetic improvement in dairy cattle, and its main functions are to associate or to complement desirable characteristics of different races, achieving animals best suited to production systems and well adapted to the environment (McMANUS et al., 2008). 
European breed cattle, such as Holstein, are more productive and specialized for milk production, but somewhat mismatched to warm environments, to endoparasites and ectoparasites, and to handling conditions existing in Brazil. Zebu breeds are less productive, but highly suited to less sophisticated managements and warm weather conditions. Therefore, most of the Brazilian dairy farmers choose crossbreeds between European and Zebu breeds (VERNEQUE et al., 2008). Thus, nearly $70 \%$ of the Brazilian milk production comes from crossbred Holstein-Zebu cows (CARVALHO et al., 2003).

Therefore, this study focused on assessing morphological differences and physiological parameters in haircoat of crossbred dairy heifers, during winter and summer, and in two periods of the day - morning and afternoon, under tropical conditions, estimating the adaptive capacity of these animals to weather variations in this region.

\section{Material and Methods}

All of the procedures in this study were approved by the Ethics Committee of the Use of Animals (CEUA), Federal University of Uberlândia, under the number 159/13 Protocol.

This study was conducted at the farm Cachoeira do Cervo, located in the city of Ibiá, Minas Gerais state, Brazil (19०29' 22" S latitude, 46³2' 50" W longitude and $895 \mathrm{~m}$ altitude). The city is located within the micro-region of Triângulo Mineiro and Alto Paranaíba, western state of Minas Gerais. According to Oliveira et al. (2012), considering the Köppen's classification, local climate is an Aw type (tropical savanna with dry winter), that is, dry winters and rainy summers.

Twenty dairy heifers were used for evaluations. The animals were about 1 year old, all healthy, and weighing between 103 and $175 \mathrm{~kg}$ (March 2014) and from 178 to $361 \mathrm{~kg}$ (August 2014). The heifers are offspring of crossing between Holstein-Gyr cows and Guzerá bulls. They were organized in a completely randomized design, each animal being a replication. The animals were reared in pasture of Urochloa syn. Brachiaria with troughs for mineral supplementation and water ad libitum during the entire year.

During the days of data collection, the heifers remained in a handling corral from 08:00 am to 05:00 pm, under no shading. Respiratory and heart rates, surface and rectal temperatures were measured both in the morning and in the afternoon. Haircoat thickness and hair sampling were made once a day, on March 15 (summer) and August 2 (winter) in 2014.

Respiratory rate was estimated by counting right flank movements per minute. Heart rate was measured by auscultating between the third and fifth intercostal space per minute, with the aid of a stethoscope (Littmann Master Classic). Surface temperatures of head, withers, groin and shank were measured in each animal by portable digital infrared thermometer (Instrutemp model DT 8530 and emissivity of 0.95 ); then, estimating the average among the four parts, each time, by season. Rectal temperature was taken with a digital clinical thermometer (TH-150 model G.TECH) inserted nearly $5 \mathrm{~cm}$ into the rectum, for two minutes.

Haircoat thickness was the measure between skin surface and hair tips, in centimetres. It was measured $20 \mathrm{~cm}$ below the spinal column, within the mid-thoracic region, by introducing an analogue calliper (Mitutoyo) perpendicularly to the animal skin surface, as described by Silva (2000). Hereafter, hair samplings were taken from the same abovementioned area, using adapted pliers and packing them into envelopes. The number of hairs per unit area (fibres per $\mathrm{cm}^{2}$ ) was obtained by counting the number of hairs in a sample, which corresponds to an area of $0.1344 \mathrm{~mm}^{2}$; then, it was converted to squared centimetres. Hair average length, in $\mathrm{mm}$, was obtained by choosing the ten largest (visual measure) from each sample, measuring them with 
an analogue calliper (Mitutoyo). Hair inclination angle in relation to the epidermis surface was determined according to Berry and Shanklin (1962):

$$
\alpha=\operatorname{arcsen}\left[\frac{\text { Haircoat thickness }}{\text { Average hair length }}\right]
$$

Whilst sampling, air temperature and humidity were measured every half hour by a psychrometer (Incoterms) and air speed by an anemometer (Instrutherm AD-250) (Table 1). Temperature and humidity index (THI) was calculated as proposed by Thom (1959):

$$
T H I=t d b+0.36+t d p+0.42
$$

Wherein: $\mathrm{t}_{\mathrm{db}}$ is the dry bulb temperature $\left({ }^{\circ} \mathrm{C}\right)$ and, $\mathrm{t}_{\mathrm{dp}}$ is the dew-point temperature $\left({ }^{\circ} \mathrm{C}\right)$.

And the Equivalent Temperature Index (ETI) according to Baeta et al. (1987) cited by Silva (2000):

$$
\begin{gathered}
E T I=27.88-0.456 t a+0.010754 t a^{2}-0.490 H+0.00088 H^{2}+1.1507 S-0.126447 S^{2} \\
+0.0198776 \mathrm{Hta}-0.046313 S \mathrm{ta}
\end{gathered}
$$

Wherein: $\mathrm{t}_{\mathrm{a}}$ is the air temperature $\left({ }^{\circ} \mathrm{C}\right), \mathrm{H}$ relative humidity $(\%)$ and $\mathrm{S}$ is the wind speed $\left(\mathrm{m} \mathrm{s}^{-1}\right)$.

The findings of haircoat variables were analyzed under a randomized block design (haircoat thickness, hair number per area unit, hair average length, hair inclination angle), considering animal live weight as covariate. The other variables (rectal, head, withers, groin and shank and skin surface temperatures, plus respiratory and heart rates) were evaluated in a randomized block experimental design with split plots; seasons were the plots, and daytime the subplots. The data showing normality and homogeneity were analyzed by analysis of variance and the means compared by the $\mathrm{F}$ test at $5 \%$ probability. Those that did not meet the assumptions (heart and respiratory rates and surface average temperature per season) were compared using the Mann Whitney's test at 5\% probability.

Table 1. Thermal environment characterization during sampling days in Cachoeira do Cervo farm, located in the city of Ibiá, Minas Gerais state (Brazil), in the morning and the afternoon. 2014.

\begin{tabular}{cccccc}
\hline & & Air temperature $\left({ }^{\circ} \mathrm{C}\right)$ & Relative Humidity $(\%)$ & THI & ETI $\left({ }^{\circ} \mathrm{C}\right)$ \\
\hline \multirow{2}{*}{ March } & Mean & 24.9 & 69.3 & 74 & 28 \\
$($ Morning) & Minimum & 23.5 & 67.1 & 73 & 27 \\
& Maximum & 26.0 & 72.8 & 76 & 29 \\
\hline \multirow{2}{*}{ March } & Mean & 32.6 & 39.3 & 81 & 32 \\
(Afternoon) & Minimum & 31.0 & 38.0 & 79 & 31 \\
& Maximum & 33.5 & 40.3 & 82 & 33 \\
\hline \multirow{2}{*}{ August } & Mean & 25.2 & 46.3 & 72 & 25 \\
(Morning) & Minimum & 22.5 & 31.9 & 70 & 24 \\
& Maximum & 28.0 & 61.3 & 74 & 27 \\
\hline \multirow{2}{*}{ August } & Mean & 27.0 & 27.6 & 71 & 25 \\
(Afternoon) & Minimum & 26.0 & 23.9 & 71 & 25 \\
& Maximum & 28.0 & 34.4 & 73 & 26 \\
\hline
\end{tabular}

THI: Temperature and Humidity Index; ETI: Equivalent Temperature Index. 


\section{Results and Discussion}

When analysing daytime, we found that afternoon rectal temperature was higher in summer compared to winter (Table 2). This result might have be due to the increasing environmental temperatures during summer (Table 1). However, this physiological parameter remained near normal range of thermal comfort for cattle, which is between 37.5 and $39.3{ }^{\circ} \mathrm{C}$ (SILVA, 2007).

Table 2. Rectal temperature means and standard deviations $\left({ }^{\circ} \mathrm{C}\right)$ of Holstein-Gyr x Guzerá crossbreed dairy heifers, in summer and winter, in the morning and afternoon, Triângulo Mineiro/ Alto Paranaíba, MG (Brazil).

\begin{tabular}{lcc}
\hline \multicolumn{1}{c}{ Daytime } & March (Summer) & August (Winter) \\
\hline Morning & $38.96 \pm 0.36 \mathrm{Aa}$ & $39.05 \pm 0.42 \mathrm{Aa}$ \\
Afternoon & $39.53 \pm 0.37 \mathrm{Bb}$ & $39.29 \pm 0.27 \mathrm{Ba}$ \\
\hline
\end{tabular}

Means followed by the same lowercase letter in the line and uppercase in the column do not differ from each other statistically by the $\mathrm{F}$ test $(\mathrm{P}>0.05)$.

Conversely, rectal temperatures had no differences between summer and winter for the morning time (Table 2). One possible explanation for this outcome was the nearness of values for both summer and winter morning temperatures, being close to the thermoneutral zone for dairy heifers, which is from 10 to $27^{\circ} \mathrm{C}$ as stated by Nääs (1989) (Table 1). THIs were also below the critical values cited by Azevedo et al. (2005), which is 80 for halfbred Holstein-Zebu. ETI values in the morning were close to the comfort zone $\left(18\right.$ to $27^{\circ} \mathrm{C}$ ) for Holstein cows, according to Baeta et al. (1987). In addition, Ferreira et al. (2006) observed similar rectal temperatures in summer and winter for crossbreed dairy cattle, in the morning time.
When evaluating the seasons separately, we observed that the highest rectal temperature was measured in the afternoon (Table 2). This result may be explained by an increase in environmental temperature throughout the day (Table 1). Oliveira et al. (2011) also found higher values for this variable in Holstein lactating cows at $6 \mathrm{pm}$ compared to 6 am and $12 \mathrm{pm}$. These authors explained these values because of the larger amount of accumulated heat by cows throughout the day, and they stated that this heat accumulation could be even greater due to high ambient temperatures.

Heart and respiratory rates showed no significant differences $(\mathrm{P}>0.05)$ comparing the daytimes (Table 3). It was an unexpected result, since as claimed by Ferreira et al. (2006), dairy cattle tend to increase respiratory rate before raising rectal temperature, for the purpose of increasing heat dissipation and maintaining body temperature within normal limits. In this study, rectal temperature in the afternoon was higher than in the morning; therefore, it was expected higher respiratory rates in that period, which did not occur. One possible explanation is because of a higher food intake during the daytime compared to nighttime, hence, the higher rectal temperatures.

On the contrary to our study, Silva et al. (2009) observed lower values of respiratory (movements minute ${ }^{-1}$ ) and heart (beats $\mathrm{min}^{-1}$ ) rates in Pitangueiras dairy cows during morning time (46.65 and 61.90, respectively) and in the afternoon (51.85 and 70.40, respectively). They claimed dairy cows reared in a tropical environment increase these physiological variables in the afternoon, mainly due to higher incidence of solar radiation. 
Table 3. Means and standard deviations of heart rate $\left(\right.$ beat $\left.\min ^{-1}\right)$ - HR and respiratory rate (movements $\left.\min ^{-1}\right)$ - RR and average surface temperature $\left({ }^{\circ} \mathrm{C}\right)$ - ST of Holstein-Gyr x Guzerá crossbreed dairy heifers, in summer and winter, in the morning and afternoon, Triângulo Mineiro/ Alto Paranaíba, MG (Brazil).

\begin{tabular}{lccc}
\hline & HR & RR & ST \\
\hline Morning & \multicolumn{4}{c}{ Daytime } \\
Afternoon & $66.27 \pm 12.62 \mathrm{a}$ & $31.72 \pm 15.09 \mathrm{a}$ & $37.68 \pm 3.21 \mathrm{~b}$ \\
\hline \multicolumn{4}{c}{ Season } \\
\hline August (Winter) & $58.72 \pm 8.61 \mathrm{a}$ & $29.75 \pm 9.20 \mathrm{a}$ & $35.24 \pm 2.82 \mathrm{a}$ \\
March (Summer) & $78.60 \pm 12.20 \mathrm{~b}$ & $34.00 \pm 9.28 \mathrm{~b}$ & $34.94 \pm 2.95 \mathrm{a}$ \\
\hline
\end{tabular}

Means followed by the same letter do not differ from each other statistically by the $\mathrm{F}$ test ( $\mathrm{P}>0.05)$ (Daytime) and by the Mann Whitney's test ( $\mathrm{P}>0.05)$ (Season).

Surface temperature averages were higher in the morning compared to the afternoon (Table 3 ). Newly, it was not expected since this variable undergoes environmental influence and we observed most thermal discomfort in the afternoon (Table 1).

Heart and respiratory rates, as well as average surface temperature were higher in summer compared to winter (Table 3). When air temperature rises, dairy cattle mechanisms try to increase heat dissipation to the environment, especially by evaporation, in an attempt to maintain homeothermy; as a result, there is increased respiratory rates. The higher heart rate in animals under heat stress is explained by a peripheral vasodilatation mechanism that increases heat flow dissipation. In environmental temperatures above $29^{\circ} \mathrm{C}$, as in this study in summer afternoons (Table 1), heifers begin to undergo a heat stress situation, experiencing changes in their physiological parameters (JOHNSON, 1985).

In this study, heifers showed respiratory and cardiac frequencies within the normal range, since, under thermal comfort, cattle have respiratory rates between 10 and 30 movements minute $^{-1}$ (FERREIRA et al., 2006) and heart rates from 60 to 80 beats minute ${ }^{-1}$ (NÄÄS; ARCARO JÚNIOR, 2001).
Variations in body surface and environment temperatures are related to convective heat dissipation. As surface and environmental temperatures drift far from each other, convective heat dissipation increases, and when this gradient decreases, convection heat loss decreases (SOUZA JUNIOR et al., 2010). In summer, head, withers, groin and shank surface temperatures were superior to those in winter (Table 4), i.e. the higher the environmental temperature, the greater the surface temperature. Here, the highest environmental temperature was registered in the summer (Table 1). In addition, Souza Junior et al. (2010) evaluated Holstein cows exposed to direct sunlight in a semiarid region and noted haircoat temperature peak concurrent with higher records of air temperature. These authors observed maximum values of haircoat surface and environment temperatures $\left(44.0\right.$ and $\left.33.7{ }^{\circ} \mathrm{C}\right)$ at 12 $\mathrm{pm}$, and the lowest values $\left(33.1\right.$ and $\left.28.6^{\circ} \mathrm{C}\right)$ at 6 pm, respectively.

The surface temperatures of head and withers were higher in the morning compared to the afternoon evaluations; however, the same was not observed for groin and shank temperatures (Table 4). Once more, a surprising result due to the superior temperatures recorded in the afternoon period. 
Table 4. Means and standard deviations of surface temperature in different body parts - ST $\left({ }^{\circ} \mathrm{C}\right)$ of Holstein-Gyr x Guzerá crossbreed dairy heifers, in summer and winter, in the morning and afternoon, Triângulo Mineiro/ Alto Paranaíba, MG (Brazil).

\begin{tabular}{lcccc}
\hline & ST head & ST withers & ST groin & ST shank \\
\hline \multicolumn{5}{c}{ Season } \\
\hline August (Winter) & $38.49 \pm 8.30 \mathrm{a}$ & $35.29 \pm 1.70 \mathrm{a}$ & $33.53 \pm 1.36 \mathrm{a}$ & $32.45 \pm 3.40 \mathrm{a}$ \\
March (Summer) & $41.19 \pm 6.01 \mathrm{~b}$ & $38.49 \pm 2.20 \mathrm{~b}$ & $36.80 \pm 2.13 \mathrm{~b}$ & $35.42 \pm 3.50 \mathrm{~b}$ \\
\hline \multicolumn{5}{c}{ Daytime } \\
\hline Morning & $43.42 \pm 7.40 \mathrm{a}$ & $37.77 \pm 2.69 \mathrm{a}$ & $34.90 \pm 2.29 \mathrm{a}$ & $34.63 \pm 4.56 \mathrm{a}$ \\
Afternoon & $36.27 \pm 5.27 \mathrm{~b}$ & $36.01 \pm 2.03 \mathrm{~b}$ & $35.43 \pm 2.54 \mathrm{a}$ & $33.24 \pm 2.56 \mathrm{a}$ \\
\hline
\end{tabular}

Means followed by the same letter in the column do not differ from each other statistically by the Mann Whitney's test (P>0.05) for seasons and by the $\mathrm{F}$ test $(\mathrm{P}>0.05)$ for daytime.

In summer, haircoat thickness and hair length achieved the lowest values if compared to those obtained in winter (Table 5). Such outcome is similar to the findings of Ferreira et al. (2009), who found values of $1.58 \mathrm{~cm}$ and $1.04 \mathrm{~cm}$ for bovine hair length in winter and summer, respectively. It can be explained through the favouring of convection heat dissipation and evaporation by haircoat characteristics. Therefore, haircoat is an important regulator of heat exchange between animal body and the environment, undergoing several changes due to season conditions, for instance (AIURA et al., 2014). These authors evaluated Holstein x Gyr crossbred cows and observed lower values of hair density (306.3 hairs $\left.\mathrm{cm}^{-2}\right)$, hair length $(0.67 \mathrm{~cm})$ and haircoat thickness $(0.271 \mathrm{~cm})$ in summer compared to winter (580.7 hairs $\mathrm{cm}^{2}, 1.19 \mathrm{~cm}, 0.306 \mathrm{~cm}$, respectively), stating that thermolysis is favoured by these characteristics.

Table 5. Means and standard deviations of haircoat morphological characteristics of Holstein-Gyr x Guzerá crossbreed dairy heifers, in summer and winter, in the morning and afternoon, Triângulo Mineiro/ Alto Paranaíba, MG (Brazil).

\begin{tabular}{lcccc}
\hline \multicolumn{1}{c}{ Season } & Thickness $(\mathrm{cm})$ & Hair length $(\mathrm{cm})$ & Hair density (hairs cm ${ }^{-2}$ ) & Inclinations $\left(^{\circ}\right)$ \\
\hline Winter & $0.73 \pm 0.17 \mathrm{~b}$ & $1.82 \pm 0.30 \mathrm{~b}$ & $1841.89 \pm 615.23 \mathrm{a}$ & $24.43 \pm 6.28 \mathrm{a}$ \\
Summer & $0.49 \pm 0.07 \mathrm{a}$ & $1.11 \pm 0.25 \mathrm{a}$ & $1358.25 \pm 453.77 \mathrm{a}$ & $27.81 \pm 7.78 \mathrm{a}$ \\
\hline
\end{tabular}

Means followed by the same letter do not differ from each other statistically by the $\mathrm{F}$ test $(\mathrm{P}>0.05)$.

Mata e Silva et al. (2013) assessed alterations in hair density, haircoat thickness, hair length and surface temperature in predominantly black Holstein cows during the periods of July to August ( $\mathrm{T}_{\text {med }}$ of $23.8{ }^{\circ} \mathrm{C}$ and $\mathrm{RH}$ of $50 \%$ ) and October to November $\left(\mathrm{T}_{\text {med }}\right.$ of $29.0^{\circ} \mathrm{C}$ and $\mathrm{RH}$ of $53 \%$ ). In October-November, haircoat became less dense with shorter hairs compared to July-August, without any differences for haircoat thickness. Density and length values were 953 hairs $\mathrm{cm}^{-2}$ and $11.7 \mathrm{~mm}$ (July-
August), and 477 hairs $\mathrm{cm}^{-2}$ and $8.0 \mathrm{~mm}$ (OctoberNovember). Yet haircoat surface temperature was higher in October-November $\left(34.3^{\circ} \mathrm{C}\right)$ whether compared to July-August $\left(30.8^{\circ} \mathrm{C}\right)$.

\section{Conclusions}

Even though both season and daytime interfered with most of the haircoat physiological parameters and morphological characteristics in Holstein- 
Gyr x Guzerá heifers; the animals could maintain homeothermy, being thus well adapted to the weather conditions in the region under study.

\section{References}

AIURA, A. L. O.; AIURA, F. S.; SANTOS, P. D. O.; SANTOS, L. V.; SANTANA, C. J. L.; GONÇALVES, G. A. M.; MARTINS, S. C. S. G. Características morfológicas do pelame de vacas mestiças. Revista Brasileira de Saúde e Produção Animal, Salvador, v. 15, n. 4, p. 866-871, out./dez. 2014.

AZEVEDO, M.; PIRES, M. F. A.; SATURNINO, H. M.; LANA, Â. M. Q.; SAMPAIO, I. B. M.; MONTEIRO, J. B. N.; MORATO, L. E. Estimativa de níveis críticos superiores do índice de temperatura e umidade para vacas leiteiras 1/2, 3/4 e 7/8 Holandês-Zebu em lactação. Revista Brasileira de Zootecnia, Viçosa, MG, v. 34, n. 6, p. 2000-2008, 2005.

BAETA, F. C., N. F. MEADOR, M. D. SHANKLIN, AND H. D. JOHNSON. Equivalent temperature index at temperatures above the thermoneutral for lactating dairy cows. ASAE Paper No. 874015. American Society of Agricultural Engineers (ASAE), St. Joseph, MI. 1987.

BERRY, I. L.; SHANKLIN, M. D. Environmental physiology and shelter engineering. LXIV. Physical factors affecting thermal insulation of livestock hair coats. Bull, v. 802, 1961.

BIANCHINI, E.; McMANUS, C.; LUCCI, C. M.; FERNANDES, M. C. B.; PRESCOTT, E.; MARIANTE, A. da S.; EGITO, A. A. Características corporais associadas com a adaptação ao calor em bovinos naturalizados brasileiros. Pesquisa Agropecuária Brasileira, Brasília, v. 41, n. 9, p. 1443-1448, set. 2006.

BOHMANOVA, J.; MISZTAL, I.; COLE, J. B. Temperature-humidity indices as indicators of milk production losses due to heat stress. Journal of Dairy Science, Lancaster, v. 90, n. 4, p. 1947-1956, 2007.

CARVALHO, L. A.; NOVAES, L. P.; GOMES, A. T.; MIRANDA, J. E. C.; RIBEIRO, A. C. C. L. Sistema de produção de leite. Zona da Mata Atlântica: EMBRAPA, jan. 2003. Disponível em: <http:// sistemasdeproducao.cnptia.embrapa.br/FontesHTML/ Leite/LeiteZonadaMataAtlantica/racas1.html>. Acesso em: 23 out. 2013.

FAÇANHA, D. A. E.; SILVA, R. G.; MAIA, A. S. C.; GUILHERMINO, M. M.; VASCONCELOS, A. M. Variação anual de características morfológicas e da temperatura da superfície do pelame de vacas da raça Holandesa em ambiente semiárido. Revista Brasileira de Zootecnia, Viçosa, MG, v. 39, n. 4, p. 837-844, 2010.

FERREIRA, F.; CAMPOS, W. E.; CARVALHO, A. U.; PIRES, M. F. A.; MARTINEZ, M. L.; SILVA, M. V. G. B; VERNEQUE, R. S.; SILVA, P. F. Taxa de sudação e parâmetros histológicos de bovinos submetidos ao estresse calórico. Arquivo Brasileiro de Medicina Veterinária e Zootecnia, Belo Horizonte, v. 61, n. 4, p. 763-768, 2009.

FERREIRA, F.; PIRES, M. F. A.; MARTINEZ, M. L.; COELHO, S. G.; CARVALHO, A. U.; FERREIRA, P. M.; FACURY FILHO, E. J.; CAMPOS, W. E. Parâmetros fisiológicos de bovinos cruzados submetidos ao estresse calórico. Arquivo Brasileiro de Medicina Veterinária e Zootecnia, Belo Horizonte, v. 58, n. 5, p. 732-738, 2006.

FERREIRA, R. A. Ambiência em construções rurais para bovinos leiteiros. In: Maior produção com melhor ambiente para aves, suínos e bovinos. Viçosa, MG: Aprenda Fácil, 2005. p. 214-266.

JOHNSON, H. D. Physiological responses and productivity of cattle. In: YOUSEF, M. K. (Ed.). Stress physiology in livestock. Florida: Boca Raton, 1985. p. 3-23.

LIMA, I. A.; AZEVEDO, M.; BORGES, C. R. A.; FERREIRA, M. A.; GUIM, A.; ALMEIDA, G. L. P. Thermoregulation of Girolando cows during summertime, in Pernambuco State, Brazil. Acta Scientiarum, Maringá, v. 35, n. 2, p. 193-199, apr./june 2013.

MATA e SILVA, B. C.; ALMEIDA, A. C.; MARQUES, L. C. G.; PORTO, B. R.; DURÃES, C. R. S.; CARVALHO JÚNIOR, I. S.; COLEN, F. Características morfológicas do pelame de vacas holandesas puras por cruza na região semiárida de Minas Gerais. Arquivo Brasileiro de Medicina Veterinária e Zootecnia, Belo Horizonte, v. 65, n. 6, p. 1767-1772, 2013.

McMANUS, C.; TEIXEIRA, R. A.; DIAS, L. T.; LOUVANDINI, H.; OLIVEIRA, E. M. B. Características produtivas e reprodutivas de vacas Holandesas e mestiças Holandês x Gir no Planalto Central. Revista Brasileira de Zootecnia, Viçosa, MG, v. 37, n. 5, p. 819823, 2008.

NÄÄS, I. A. Princípios de conforto térmico na produção animal. São Paulo: Ícone, 1989. 183 p.

NÄÄS, I. A.; ARCARO JÚNIOR, I. Influência de ventilação e aspersão em sistemas de sombreamento artificial para vacas em lactação em condições de calor. Revista Brasileira de Engenharia Agrícola e Ambiental, Campina Grande, v. 5, n. 1, p. 139-142, 2001. 
O'BRIEN, M. D.; RHOADS, R. P.; SANDERS, S. R.; DUFF, G. C.; BAUMGARD, L. H. Metabolic adaptations to heat stress in growing cattle. Domestic Animal Endocrinology, Beeville, v. 38, n. 2, p. 86-94, 2010.

OLIVEIRA, L. A.; FALEIROS, F. E.; SANTOS, J. A. S. Análise do condicionamento da altitude nas variáveis climáticas de temperatura e precipitação na mesorregião do Triângulo Mineiro e Alto Paranaíba. Revista GeoNorte, Manaus, v. 1, n. 5, p. 325-335, 2012. Disponível em: <http://www.revistageonorte.ufam. edu.br/attachments/013_\%28AN\%C3\%81LISE\%20 D O \% 20 C ON D I C I ON A M EN T O \% 20 D A \% 20 ALTITUDE $\% 20$ NAS\%20VARI\%C3\%81VEIS\%20 C L I M \% C $3 \% 81$ T I C A S \% 20 D E \% 20 TEMPERATURA \% 20 E \% 20 P R E C IPITA \% C $3 \% 87 \%$ C $3 \% 83$ O \% $20 \mathrm{~N} \mathrm{~A} \% 20$ MESORREGI\%C3\%830\%20D\%29.pdf>. Acesso em: 05 mar. 2015.

OLIVEIRA, N. J. F.; MATA e SILVA, B. C.; ALMEIDA, A. C.; VIEIRA, V. A.; BARBOSA, L. K. G.; SOUZA, D. S.; FÉLIX, T. M. Temperatura retal, frequência respiratória e hemograma de vacas leiteiras holandesas em lactação no norte de Minas Gerais. Veterinária e Zootecnia, Botucatu, v. 18, n. 4, p. 438-441, 2011. Suplemento 3.
SILVA, E. C. L.; MODESTO, E. C.; AZEVEDO, M.; FERREIRA, M. A.; DUBEUX JUNIOR, J. C. B.; SCHULER, A. R. P. Efeitos da disponibilidade de sombra sobre o desempenho, atividades comportamentais e parâmetros fisiológicos de vacas da raça Pitangueiras. Acta Scientiarum, Maringá, v. 31, n. 3, p. 295-302, 2009.

SILVA, R. G. Biofisica ambiental: os animais e seu ambiente. São Paulo, Jaboticabal: Funep, 2007. 300 p.

. Introdução à bioclimatologia animal. São Paulo: Nobel, 2000. 283 p.

SOUZA JUNIOR, J. B. F.; SILVA, R. B.; DOMINGOS, H. G. T.; MAIA, A. S. C. Temperatura da superfície corporal e fluxo de calor convectivo em vacas holandesas expostas à radiação solar direta no semi-árido. Revista Científica de Produção Animal, Teresina, v. 12, n. 1, p. 6-9, 2010.

THOM, E. C. The discomfort index. Weatherwise, Boston, v. 12, n. 1, p. 57-60, 1959.

VERNEQUE, R. S.; PEIXOTO, M. G. C. D.; TEODORO, R. L.; MACHADO, M. A. Cruzamento para produção de leite. In: SIMPÓSIO SOBRE BOVINOCULTURA LEITEIRA, 6., 2008, Piracicaba. Anais... Piracicaba: FEALQ, 2008. p. 81-102. 
